DOI: $10.15587 / 2706-5448.2021 .239112$ Article type «Reports on Research Projects»

\author{
Nataliia Tiron-Vorobiova, \\ Anatoliy Danylyan
}

\title{
ANALYSIS OF THE EXPERIMENTAL BALLAST WATER TREATMENT SYSTEM
}

The object of research is the experimentally created model of the accompanying ballast water treatment systems (BWTS) at the Danube Institute of the National University «Odessa Maritime Academy» (Izmail, Odessa region, Ukraine). The study is aimed at assessing the compliance of ballast water quality standard D-2 ballast water operational cycles by disinfection and purification. One of the most problematic places of the presented research is the renewal (acquisition) of a separate node segmentation of the experimental BWTS with attraction of certain material support (investment). In particular, it is the scaling of BWTS, presentation in the state market of Ukraine, abroad (competition), qualitative assessment, certification at the level of the Ukrainian Sea Ports Administration (USPA), the register of maritime shipping.

Elimination of the above «problem-tasks» will contribute to the collective research support, opinion and effective steps of professionals-researchers, in particular, in the maritime industry (experts IMO - International Maritime Organization, professors, academicians TAS - Transport Academy of Sciences). Also, compatible contribution of significant research results to separately oriented projects (European, Ukrainian) with attraction of investors, mentors, maritime industry business.

The research used modern practices of design of such accompanying BWTS, referring to innovative methods, methodologies of global production of such structures of famous world brands, for example, Alfa Laval, Wartsila, OceanSaver, Hyde Marine, Industrie de Nora, etc. Researchers have qualitatively and consistently studied the generally accepted series of technological processes for ballast water treatment, observing classical according to the analytical review of literature sources and in the modern coverage (state) of similar stages of ballast water decontamination/cleaning.

Qualitative expression of the received result is a number of conducted researches of disinfection/purification of sea outboard water in laboratory conditions on experimental BWTS. Thanks to the latter the reliability of the presented data is provided, which coincide (are identical) with trustworthy, established by the BW quality standard D-2, that are specified in discussion and conclusion of the given work.

Keywords: marine industry, ballast water, IMO Convention, D-2 standard, associated ballast water management systems.

\section{How to cite}

Tiron-Vorobiova, N., Danylyan, A. (2021). Analysis of the experimental ballast water treatment system. Technology Audit and Production Reserves, 5 (3 (61)), 14-16. doi: http://doi.org/10.15587/2706-5448.2021.239112

\section{Introduction}

Water is an inseparable part of sea transport, and as we know, millions of ships cross the sea cordons of many countries of the world. Maritime transport carries a large amount of cargo. For ship balancing, namely, to maintain the necessary stability, roll, transport characteristics needed, as is well known, it is the water, which is the outboard, ballast. This is especially true for heavy-tonnage ships that maneuver the World Ocean all the way. All the maritime states of the World Consortium for the Control of ballast water (BW) Operations have been continually improving the legal framework to protect their maritime economic zone from invasive living species in BW ships for the past three decades. Adopted at the beginning of 2017, the standard for treatment of BW according to the IMO (Internatio- nal Maritime Organization) Convention D-2 (specifies the maximum number of living organisms that can be found in waste waters), strengthened the requirements for their purification. The entry into force of the document is an important step in the fight for the preservation of the environment. Living organisms in the diameter of 50 microns or more must not exceed 10 particles per $1 \mathrm{~m}^{3}$ of water, more deleterious organisms (10-50 microns) per $1 \mathrm{~m}^{3}$ must be less than 10 in waste waters which are discharged [1-3]. The number of bacteria in water is also limited.

All maritime states of the World Consortium for the control of BW operations over the past three decades are constantly improving the legal framework for the protection of their maritime economic zone from invasive living waste in the BW of ships. That is why this global problem is exhaustive, especially in conditions of all-round pandemic COVID-19. 
The «purification-breath» of water (not only sea water) with preservation of the marine biocenosis and diversity is related to the solution of this problem [4].

So, the research object was created experimentally a model of associated systems of ballast water treatment system (BWTS) on the basis of the Danube Institute of the National University «Odessa Maritime Academy» (DI NU «OMA», Izmail, Odessa region, Ukraine). The purpose of the investigation is assessment of compliance of working cycles of BWTS to the BW D-2 quality standard by means of disinfection and purification.

\section{Methods of research}

The study of the effectiveness of the experimental BWTS was conducted according to the generally accepted sanitary-bacteriological analysis of water for compliance with the requirements of SSR 4630-88 (in particular, Annex 1. «Hygienic requirements...»), the latter correlate with the quality standard BW D-2.

Bacteriological and sanitary-chemical studies of water were conducted in the Danube Basin Department of the State Institution «Laboratory Center of the Ministry of Health of Ukraine on Water Transport» (DBD State Institution «LC of the Ministry of Health of Ukraine on WT»). The studies were obtained based on the requirements of the quality standard of BW treatment: standard D-2 of the IMO Convention - microbes: V. Cholerae (O1 and O139), index of E. coli, P. aeruginosa, Enterococci, common coliforms, total microbial count.

The subject of the study were: the water of the Danube River (city beach area), as well as the onshore BW of the Black Sea (at a depth of $200 \mathrm{~m}$, in the 100-mile zone from the shore: the ship «Asia Opal», bulk carrier, flag Singapore, IMO number 09543885, port of destination Mykolaiv, Ukraine).

The researchers used the following parameters of the technological processes of SMS in research:

- liquid (water) flow rate - range: $0.8-1.6 \mathrm{~m} / \mathrm{s}$;

- water temperature $24.4-26.2{ }^{\circ} \mathrm{C}$;

- wavelength in the UV chamber (China) 254-260 nm;

- ozone dose 8; $83 \mathrm{mg} / \mathrm{l}$ (the latter - for BW of the

Black Sea - due to the high viability of invasive organisms: resistance).

The conducted researches are based on centuries-old practice of application of world analogues of similar BWTS of sea vessels. And they are based on a set of research works that cover a range of generally accepted processes that are configured in such systems. But, at the same time, the novelty of the research is the refinement of nodal segmentation and individual technological cycles of experimental BWTS, in order to preserve energy efficiency, increase the competitiveness of bringing BWTS to the world market of the maritime industry. However, the «framework» of conventional disinfection/purification processes is preserved and improved.

The invented solution of separate technological processes is complex and contains several stages [5]:

- chemical disinfection (sodium hypochlorite and iron chelate were used as chemical reagents);

- electrohydraulic action (electrohydraulic effect (shock) of Lev Yutkin; improved to the module of electrocoronary impulse);

- ionized processes (application of ultraviolet (UV) irradiation and ionization);
- mechanical action (filtration - developed by scientists DI NU «OMA» «self-unloading» filter with carbon inserts: high-tech nanofilter).

The experimental BWTS is presented in Fig. 1.

The principle of operation of the BWTS was as follows: the ballast tank through the reagent dispenser received iron chelate and sodium hypochlorite. The experiment was performed with alternating pulses, $\tau=10^{-6} \mu$ s at an instantaneous pulse power of 50-1000 MW (high-frequency electrohydraulic shock unit). Next, the BW was fed to the coarse filter, then with the help of a ballast pump and a water supply regulator, the initially purified BW was fed into the Venturi tube, where ozone was supplied from the ozone generator. BWTS was retrofitted with ozone generator «Ekozon-5AW» (Ukraine), with a capacity of $5 \mathrm{~g} / \mathrm{h}$. Then BW came to the fine filter («self-unloading filter»).

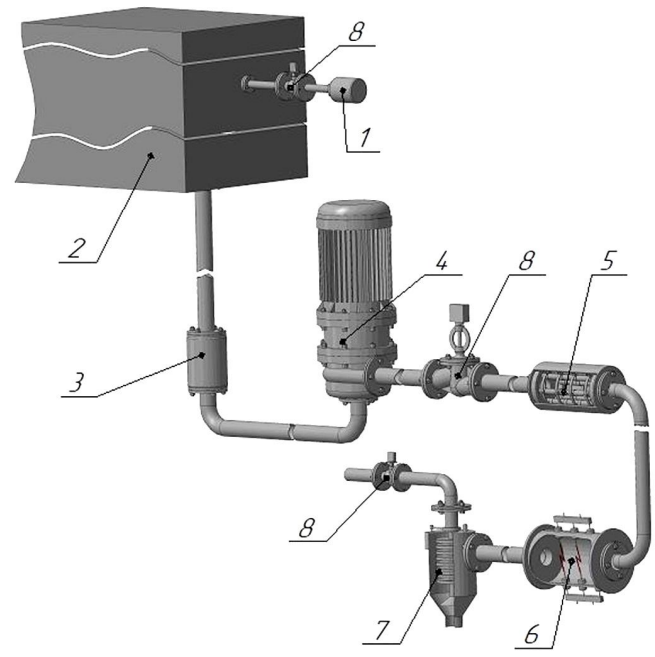

Fig. 1. 3-D format of the experimental ballast water treatment system on the basis of the Danube Institute of the National University "Odessa Maritime Academy»: 1 - dispenser; 2 - ballast tank; 3 - coarse filter; 4 - ballast pump; 5 - device for treatment of ballast water with ultraviolet light; 6 - block of high-frequency electrohydraulic shock; 7 - «self-unloading» filter; 8 - shut-off valves

The flow of BW passes in the direction from the base of the housing (hollow shaft) of the «self-unloading» filter to the peak (top), thereby «spraying» BW on the perforated areas of the filter disks, consisting of carbon nanotubes. BW, passing through the filter discs one after another, gradually becomes more and more clean. In this case, the flow of BW is constantly twisted due to the fact that the filter disks are on a hollow shaft, which is driven by an electric drive (autonomous operation of the cyclone type). Then the BW entered the UV chamber, where it was exposed to radiation. In particular, an electromagnetic effect with a high degree of UV ionization was used: a wavelength of 254-260 nm. After repeatedly cleaned BW fell overboard.

\section{Research results and discussion}

Due to the universality of the proposed process of disinfection/purification of BW experimental BWTS to the level of international rules of quality standard D-2 IMO, and, in further research, to retrofit the «corona pulse module» is the complete destruction of associated microflora.

The use of two modules (UV and ozonation) in the conducted research for disinfection/purification of the 
coastal waters of the Danube and BW of the Black Sea corresponds to the sanitary-bacteriological analysis of waters (requirements of SSR 4630-88) [6, 7].

The amount of MAFAM (mesophilic aerobic and facultative anaerobic microorganisms) in the water of the Danube River after disinfection/purification processes decreased from $1500 \mathrm{CFU} / \mathrm{cm}^{3}$ to $5 \mathrm{CFU} / \mathrm{cm}^{3}$. At the same time, the water flow rate was $V_{3 w}=0.8 \mathrm{~m} / \mathrm{s}$, the wavelength in the UV chamber was $254-260 \mathrm{~nm}$ and the ozone dose $O_{3}=8 \mathrm{mg} / \mathrm{l}$ ). The following indicators markedly decreased: LPR index (lactose-positive rods) from 1800 to 300 , phage index - from 125 to 0 , index of Enterococci - from 2300 to 700 under the same conditions. The most optimal conditions were: water flow rate $V_{3 w}=0.8 \mathrm{~m} / \mathrm{s}$, wavelength in the UV chamber $254-260 \mathrm{~nm}$, ozone dose $O_{3}=8 \mathrm{mg} / \mathrm{l}$.

Regarding the treated BW of the Black Sea (bulk carrier, port of destination Mykolaiv, Ukraine): the number of MAFAMs after exposure decreased from $5000 \mathrm{CFU} / \mathrm{cm}^{3}$ to $600 \mathrm{CFU} / \mathrm{cm}^{3}$. At the same time, the water flow rate was $V_{3 w}=0.8 \mathrm{~m} / \mathrm{s}$, the wavelength in the UV chamber was 254-260 nm, and the ozone dose $O_{3}=80 \mathrm{mg} / \mathrm{l}$. The LPR index decreased five times, at the initial value of 3900 . Phage index: from 500- $t$ to 90 . Index of Enterococci: from 7500 to 500 under the same conditions.

The energy consumption of the installation is $0.3-$ $0.4 \mathrm{~kW}$ per $1 \mathrm{~m}^{3}$, which is quite common for use on the largest ocean-going vessels, where the capacity of ballast pumping reaches $Q=6$ thousand $\mathrm{m}^{3} / \mathrm{h}$. This is the key meaning of the practical development of this study.

The limitation of the proposed study is the practical implementation of the results of disinfection/purification of ballast water, given whether the future ship-owner will probably agree to install and scale an experimental system created on the basis of DI NU «OMA» on a particular vessel. At the same time, given the comprehensive global market for related ballast water treatment systems competitiveness. The peculiarity of the research results is primarily that it is necessary to consider:

- «performance» of all key components of the given structure, features of its action;

- limited to get experimental material - BW (in the required amount and in a certain period of time): for in-depth research, in a research laboratory. The latter is confirmed at the legislative level of Ukraine [8].

\section{Conclusions}

In the course of work low results were obtained by means of testing BWTS, which was conducted on the basis of the Danube Institute of the National University «Odessa Maritime Academy». Taking into consideration the world marine practice of using subcomponent systems of BW control, the investigators showed the use of high-frequency electrocoronic pulse module (energy in one pulse: $17 \mathrm{~mJ}$ ) and nanopulse discharge with a frequency of $(7.95 \mathrm{~mJ})>2000$ discharges per second $[8,9]$.

In the conducted investigations on disinfection/purification of BW of the coastal waters of the river Danube and Black Sea BW waste water complex adjustment of all modules functioning system meets the criteria of sanitarybacteriological analysis of water SSR 4640-88, which correlate with the standard of quality BW D-2.
When using the filter with nano-carbon tubes the inclusion of living organisms is ensured (its value is $10-$ at a primary value of 40: at the most per $1 \mathrm{~cm}^{3}$ ) [10].

At the desire of the shi-powner, filtering nanotechnological discs can be replaced with discs of cheaper fibers, cellulose and other materials. But with this replacement, it will be necessary to connect an additional unit of the tested system: an improved electrocoronary pulse module).

The unit is unversatile and can be used in the processes of disinfection/purification of wastewaters of municipal sewage treatment plants and large enterprises.

\section{References}

1. Anonymous (2004). International convention for the control and management of ships' ballast water and sediments. BWM CONF/36:38. London: IMO.

2. Anonymous (2005). Guidelines for approval of ballast water management systems (G8). Annex 3. MEPC. 125(53). London: IMO.

3. ClassNK (2021). Latest Information of Approval of Ballast Water Management System (G8 MEPC174 (58)). Available at: https:// www.classnk.or.jp/hp/pdf/activities/statutory/ballastwater/approval_ballast_e.pdf

4. Tsolaki, E., Diamadopoulos, E. (2010). Technologies for ballast water treatment: a review. Journal of Chemical Technology $\&$ Biotechnology, 85 (1), 19-32. doi: http://doi.org/10.1002/jctb.2276

5. Tiron-Vorobiova, N. B., Danylyan, A. H., Chymshyr, V. I., Maslov, I. Z., Naydyonov, A. I., Romanovska, O. R. (2020). Scientific Impact on The Fighting Invasive Species in the Ballast Water of Seagoing Vessels. 36th IBIMA Conference. Granada, 10533-10538. Available at: https://ibima.org/accepted-paper/ scientific-impact-on-the-fighting-invasive-species-in-the-ballastwater-of-seagoing-vessels /

6. SanPiN 4630-88. Sanitarnye pravila i normy okhrany poverkhnostnykh vod ot zagriazneniia (status: zamenen, data aktualizatsii: 01.02.2020). Available at: https://meganorm.ru/Index2/ $1 / 4294853 / 4294853854 . h t m$

7. HD 2-030101-030. Rukovodstvo po primeneniiu trebovani mezhdunarodnoi konventsii o kontrole sudovykh ballastnykh vod $i$ osadkov $i$ upravleniiu imi 2004 goda (2017). Saint Petersburg. Available at: https://files.stroyinf.ru/Data2/1/ 4293746/4293746524.pdf

8. Primenenie vysokovoltnykh istochnikov pitaniia v elektrogidravlicheskom effekte Iutkina. Available at: http://bourabai.kz/ physics/yutkin.htm

9. Tiron-Vorobiova, N. B., Danylian, A. H., Maslov, I. Z., Romanovska, O. R. (2020). Elektrokoronnyi rozriad dlia znezarazhennia i ochyshchennia balastovykh vod vidpovidno mizhnarodnykh vymoh standartu D-2 IMO. Stalyi rozoytok: zakhyst navkolyshnoho seredovyshcha. Enerhooshchadnist. Zbalansovane pryrodokorystuvannia. Lviv: Zakhidno-Ukrainskyi Konsaltynh Tsentr (ZUKTs), TzOV, 74. Available at: http://science.lpnu.ua/ uk/ekokongres-2020

10. USCG (2012). Standards for Living Organisms in Ships' Ballast Water Discharged in U.S. Waters (Final Rule). RIN 1625-AA32. D. o. H. S. (DHS). Federal Register. 33 CFR 151: 17253-17320. Washington.

$\triangle$ Nataliia Tiron-Vorobiova, PhD, Associate Professor, Department of General Scientific Disciplines, Danube Institute of National University «Odessa Maritime Academy», Izmail, Odessa region, Ukraine, ORCID: https://orcid.org/0000-0002-8269-2682, e-mail: natasha.vorobyova051982@gmail.com

Anatoliy Danylyan, Senior Lecturer, Department of Ships Power Plants and Systems, Danube Institute of National University «Odessa Maritime Academy», Izmail, Odessa region, Ukraine, ORCID: https:// orcid.org/0000-0002-9468-2756

$\triangle$ Corresponding author 